\title{
From the chaos of transition economy to "normalized" managerial practices: The role of group interaction in creating meaning in managerial work
}

\author{
Svetlana Serdukov ${ }^{* *}$
}

The purpose in this paper is to explore the interplay between managerial sensemaking, representations and identity in the context of a transition economy. Using the approach of theory of social representations (Moscovici, 1961), a thirteen year long observation of a group of twelve owners/managers was adopted. The research concluded that managerial practices emerged in social interaction. These practices existed in relations of co-production and were embedded in the social construct. During the transition period, the content of managerial actions, narratives and identity changed in the same way under the influence of shared culture, ideologies and day-to-day social practices. This is one of the rare longitudinal studies of transition economies where the process of emergence of a small social group was observed and the pattern of evolution identified.

Zweck dieser Arbeit ist die Untersuchung des Zusammenspiels zwischen Sensemaking, Repräsentationen und Identität im Kontext einer TransitionsWirtschaft. Auf der Grundlage der Theorie der sozialen Repräsentationen (Moscovici, 1961) wurde eine Gruppe von 12 Eigentümern/Managern während 13 Jahren beobachtet. Die Untersuchungen ergaben, dass Managementpraktiken in der sozialen Interaktion entstehen. Diese Praktiken bestanden aus den Beziehungen der Co-Produktion und wurden in ein soziales Konstrukt eingebettet. Während der Übergangszeit wandelte sich der Inhalt des Managerhandelns, der Narrationen und der Identität in gleicher Weise unter dem Einfluss der gemeinsamen Kultur, Ideologien und von alltäglichen sozialen Praktiken. Dies ist eine der seltenen Längsschnittstudien über TransitionsWirtschaften, in denen der Prozess der Entstehung einer kleinen sozialen Gruppe beobachtet und ihr Evolutionsmuster identifiziert wurde.

Key-words: transition, ideology, identity, longitudinal, Kazakhstan

\footnotetext{
Manuscript received:23.01.2012, accepted: 19.05.2012 (0 revision)

** Dr. Svetlana Serdukov, Associate Dean Head of Research and Professor, Reims Management School, France. Main research areas: management education development, business development. Corresponding address: Svetlana.serdukov@reims-ms.fr
} 


\section{Introduction}

Despite a number of research studies conducted on the transition process (Lavigne 1995), there is limited literature devoted to company leaders and managers as a social group involved in social processes and not enough consideration has been given to the role of human subjectivity in this context (Fotaki 2009). Very often content, process and context were studied separately by organizational scholars (Pettigrew 1987; 1990; 1992) and much richness was overlooked concerning the relationship between these elements. The purpose in this paper is to explore the process of interaction between managerial sensemaking and identity during transition. How do company managers make sense of their environment and their-own actions? How do they constitute their representations of a changing world and of themselves? How do they express these representations in their discourse? How does 'what they say' relate to 'what they do'? These questions focus on key elements of the process, which are interrelated and mutually constitutive.

This paper is the result of an empirical longitudinal study, focused on the development in private company manager practices during the transition from a planned to a market economy in Kazakhstan, one of the 15 former republics of the Soviet Union, which became independent in 1991. It aimed to investigate how the changes which occurred in society after the break down of the Soviet Union were perceived and enacted by entrepreneurs, identified as key-figures in this transformation process.

This paper argues that during the transition period in the post-Soviet countries new managerial practices and discourse that did not exist before perestroika were constructed by practitioners involved in this process. In ten years the old soviet-type administration was transformed into a more modern management system. This process started with the most dynamic part of the population realizing that "the economy was not working any more" and that "the world had changed". They tried to understand the change, to make sense of what had happened, to ascribe meaning to unusual events happening in society in order to take appropriate action. Such action can be taken when individuals form their representations about the environment and themselves. For them, these representations are the "true knowledge", natural logic, beliefs and guiding patterns for behavior and action (Cossette/Audet 1992; Eden 1992; Fiol/Huff, 1992). In this paper, the term "social representation" is used to enhance the collective process of their construction. Representations are deeply rooted in national culture and history, influenced by the dominant ideology and embedded in the day-to-day social practices of individuals.

The following section elucidates the concepts of sensemaking and social representation and their relationship with the other concepts of the theoretical framework of this study. Thereafter the design and the results of the empirical 
study will be presented. The paper will conclude with a discussion of its contribution in relation to managerial practices literature.

\section{From sensemaking to social representation}

This paper explores the relationship between managerial discourse/practices and social structures producing and reproducing these practices and discourse. It stresses the importance of the ideological and cultural elements involved in the social construction of reality (Berger/Luckmann 1967) and its verbal expression. These taken-for-granted, self-evident assumptions of knowledge (Huff, 1990) will be questioned in this paper by examining the processes and mechanisms of their production.

A growing stream of research has suggested that cognitive sensemaking processes are important in conducting strategic changes (Fiss/Zajac 2006) and that the company managers play a key role in this process by providing meaningful interpretations to their organizations (Thomas et al. 1993). Therefore, this paper tries to link managerial thinking, speaking and acting by using the concepts of sensemaking, representations, and strategic actions. In this research, sensemaking is understood as a process of meaning building. The sensemaking perspective (Weick et al. 2005; Gioia/ Mehra 1996; Weick, 1995; Gioia et al. 1994; Thomas et al. 1993) is appropriate because sensemaking starts "with chaos" (Weick et al. 2005), when previous understanding, representations and schemas no longer match current events and cannot be used to take appropriate action. This statement truly describes the situation in Kazakhstan as well as in all the other former republics of the Soviet Union in the early nineties. However, sensemaking theory lacks instruments to explore how current meaning is embedded in the past; how existing frameworks, beliefs and practices influence the constitution of new knowledge. Social Representations Theory fills some conceptual gaps in the sensemaking theory and offers some methodological solutions to study the process of meaning building.

According to the Social Representations Theory (Moscovici 1961; Jodelet 1989; 1984), rooted in French social psychology, representation can be viewed as a process similar to sensemaking and as a product of this process expressed in the form of images, schemas or cognitive frameworks organizing our thinking and action (Laroche 1995). According to Jodelet (1989), social representation is a form of socially developed and shared knowledge, with practical implications, which contributes to the construction of a common reality for a social group. It is important to mention three interdependent features of representations: $1 /$ they are developed in and through communication, 2/ they help to construct reality and $3 /$ they shape the surrounding environment through their organization. It is accepted that social representations constitute a system of values, ideas and practices with a twofold function; first to establish an order which will enable individuals to orient themselves in their material and social world and to master 
it; and secondly to enable communication to take place among the members of a community by providing them with a code for social exchange (Moscovici 1984).

Social representations are anchored in collective memory or otherwise in the historical and cultural construct shared by a social group; in the ideology which is dominant in the society at that period of time; and in the day-to-day social practices of individuals and social groups. (Grize et al. 1987). Therefore, different social groups can share the same representations, and yet vary from other groups which are involved in different practices and exposed to alternative ideological or cultural influences. The theory of representation anchoring (Grize et al. 1987) provides a major insight into the origin and imagination process within a context of transition.

\section{The role of group interaction and identity in the creation of managerial practices}

Managerial practices are investigated in this research through the process of social representation and appear as a product of the social interaction and sensemaking process. Within the process of sensemaking, top-managers create not only representations about their business and practices but also about themselves. The self-representation together with the sense of belongingness to the social group call for the concept of individual and social identities. Identity has been conceptualized at several levels of analysis, including individual, group, organization, and society. However, almost no research has attempted to establish multilevel linkages, although the identity construct holds the possibility of integrating multiple levels of analysis (Foreman/Whetten 2002), particularly in sociology and psychology, where scholars have depicted multiple identities as being the norm for individuals (Mead 1934; Beyer and Hannah 2002).

Identity is essentially the set of beliefs or meanings that answer the question "Who am I?" (Mead 1934). It is a general concept that refers to various types of mental representations about the self and encompasses not only personal characteristics but also attributes relevant to individuals' work, profession and position within an organization. Individual identity is constructed through cyclical, episodic exchanges with others (Mead 1934). An individual's sensemaking process is guided by a search for the coherence or the compromise between the exterior meanings, his or her self-identity, representations, past and future actions (Dutton /Jackson 1987; Gioia/Mehra, 1996).

Establishing social connections through different groups meets individuals' needs for approval and self-esteem (Murray/Holmes and Collins 2006). It refers to the definition of self vis-à-vis some group as an occupation or organization (Ashforth/Mael, 1989). Social identities are based on the belongingness to a meaningful social group (Baumeister/Leary 1995). Individuals identify 
themselves with a specific group by desire to transfer this group attributes and characteristics into their own self-image (Turner 1985). An individual may have as many social identities as he or she has group memberships. Each respondent's membership in different organizations and networks, having particular rules, values and codes requires a certain type of behavior. A person's identity is arranged as a hierarchy of different identities co-existing at the same time (Feldman 1979). An individual's identities are at least partially composed of the roles he or she plays (Pratt/Foreman 2000). The various social roles may be in contradiction with each other. Goffman (1959) suggested that individual's behaviors, similar of those of actors on a stage, are largely conducted for others in order to convey impressions that serve the actors' self-interests. At the same time, these performances have implications for a person's understanding of self in that the role represents the self the person wants to be.

\section{Empirical study}

The empirical study observes a group of private company owners and managers during the transition from a Soviet planned economy to a market economy. The group, named "New Generation" by the mass media, is composed of 12 entrepreneurs who started their businesses in the early nineties and became part of the business elite in early 2000. The creation of this group constituted an outstanding and complex phenomenon in the social and economic life of Kazakhstan. Observing this group was a major opportunity to follow the process of the constitution of new managerial practices during this period. The empirical study aims to observe the process of emergence and evolution towards the "normalization" of managerial practices in the transition economy through longitudinal analysis of verbal accounts or narratives of a group of company managers and owners. This analysis allowed the reconstruction of the content of social representations created and shared by the group about their business, practices and roles as well as about themselves. This study was guided by a threefold question:

1. How does a group of top managers give meaning to their job in the changing environment of a transition economy?

2. How does change in the group identity relate to the change in the building of meaning?

3. How do social structure and ideologies influence these managers' narratives and practices?

This research did not follow a linear process. Moving backwards and forwards between theory and the empirical data ensured the relevance of the data collected and the validity of the explanations. 


\section{Research methodology and design}

Narrative methodology was mainly used in order to access to the content of managerial representations. The meaning built within the process of sensemaking as well as managerial representations could be expressed either through actions or through stories, narratives, verbal accounts or discourses. Managers' narratives are a source of rich data not only about their practices, strategies and projects, but also about themselves. Narrative methodology also enables one to grasp the collective and social aspect of their production, which is one of the key-dimensions of this study. But it does not mean that managers say exactly what they think and do what they say. Interviews are contextually situated, which constitutes a major limitation of this method. Narratives are much more complex constructions, which certainly produce rich data, but need to be thoroughly analyzed in conjunction with other data sources.

Longitudinal in-depth case studies were conducted for each of the twelve top managers and for the group "New Generation" as a whole over a seventeen year period, 1991 to 2008 inclusive, eight years of retrospective and nine years of real time data collection. Once a year, the members of "New Generation" were interviewed during a two week visit to Kazakhstan. The interviewing process was centered on the following questions: "What is the essence of managerial work for you? What were the most important actions you took last year? Why? What will be your future actions? Why?" The following year more specific questions were asked about reported strategic action taken during the past year. The interviewing was structured in exactly the same way each year and covered the same questions with each respondent.

The research was designed in three distinctive stages, the preliminary stage being used to justify the sample choice and to describe the chosen group and the transition context. "New Generation" was selected for this research because of the intensity of the dynamic change in its activity and identity as well as because of its significant exposure in Kazakh society and its influence on business and management practices in the country. According to the local press articles in 1993-1996, this group reflects and symbolizes the overall transitional process in all former Soviet republics.

The preliminary stage led to the identification of the 12 founding members of "New Generation", mutually accepted and identified as the core of the group. Many other businessmen also identified themselves as members of this prestigious group, but were not accepted by the "core", so they were not included in the study group. The list of 23 names, built from local press articles about "New Generation", was shown to the most often cited members and they eliminated those who did not belong to the group. Only 12 members mutually identified themselves as being part of this group. 
The first stage of the research involved the collection of interviews, of internal and external documents concerning the members of "New Generation" and the direct observation. The data was collected annually and interpreted, analyzed and compared period by period. For both retrospective and real-time studies, five different sources of information were used (interviews with three different types of informants, internal documents and local press articles) and several methods of empirical data collection and analysis were adopted. The data was mainly collected by carrying out a series of semi-directive interviews once each year with: 1) "New Generation" members, in order to study the content of their managerial practices and the meaning they attributed to their work and to the context of this work; 2) their colleagues, in order to determine the strategic actions taken by the members of the group and to cross-check the information, received from other sources; 3) local researchers in the field of social and political science, in order to get an outside view on the social, economic and political context for each period of study. Moreover, local press articles devoted to the "New Generation" group and to its members were collected for the whole period, as well as the organizational documents of the twelve respective companies and of different associations and committees in which the group members participated over the period of study. In total, 62 semi-directive interviews with members of the group, 88 interviews with their colleagues and 9 interviews with local researchers were held during the period of study, which represented more than seven hundred pages of interview transcriptions. More than 280 internal documents and 81 press articles were collected and analyzed.

Transcripts of the interviews were analyzed using open coding procedures (Usinier and al. 1993) to develop conceptual labels for categories of interest. A second stage focused on data interpreting, period by period, in order to identify the content of respondents' representations and its inscription in the social context. By the end of this stage an analytical framework was elaborated to make connections between the categories identified in the narratives and the social context. The third stage represented a transversal content analysis of all collected data through the whole observation period (1991-2008): interview summaries, company documents, mass media articles about the group and its members individually. Conversation analysis (Drew /Heritage 1994), content and documentary analysis methods were used to complement each other (Isenberg 1986). Using the framework elaborated in the previous stage made it possible to elucidate the meaning production process used by the group members in relation with their strategic actions and the social context.

\section{Group "New Generation"}

The "New Generation" is a group of young company directors and owners who started up their businesses in the early $90 \mathrm{~s}$ in the commercial sector. The 
members of this group all are men and native Kazakhs ${ }^{6}$, all belong to the same generation: they were 24 to 30 years old when their careers as entrepreneurs began. Later on they organized a movement in opposition to the old political administration, the so-called "red directors", civil servants and politicians inherited from the time of the Soviet Union. The consolidating idea of this group was motivating and powerful: "To contribute to the prosperity of Kazakhstan by promoting democracy and the market economy" ${ }^{\text {" }}$. Officially this movement did not exist for a long time, crushed under the weight of criticism from the "old elite" and contradictions inside the group. The lack of political experience and organization, the picture of "climbers" and "sharks" in Kazakh society as well as their illegitimate position in the eyes of the old elite contributed to the defeat of this movement. On the other hand, the core of this group has continuously changed until 1997. Other young businessmen and entrepreneurs have identified themselves as part of a new generation of managers or leaders without being a part of the "New Generation" group. They gather in professional clubs and associations of people sharing the same profession, the same ideas on the future of their country, on business methods and objectives without pursuing any political or economic goal. In 1998, the general tone of the press about "New Generation" changed completely, because, on one hand, the group abandoned the political claims, and on the other hand, the government needed to show a progress in developing entrepreneurship and local business. The picture of young and ambitious managers greedy for power and money was replaced by the image of "young patriots, willing to serve their country", and that of "highly professional, well educated, very efficient managers - the future of the nation".

Within a period of only ten years, the group members had developed their firms into large holdings ${ }^{8}$, following the massive privatization which took place from 1992 to 1996. Some of the members of this group held office as ministers, deputy-ministers, political party leaders and heads of influential associations. In 2003 , the most politically active members of "New Generation" launched into political action by organizing a new anti-presidential political party called the DVK (Democratic Choice of Kazakhstan). All the members of "New Generation" supported them either explicitly or implicitly. This attempt was no more successful than the first one. The party folded up for insignificant reasons and another one was organized whose agenda was more moderate. After this incident, all the other members of "New Generation" focused on their businesses and limited their outside activities to the participation in professional associations, charity and cultural events.

\footnotetext{
In the early nineties, $39 \%$ of Kazakhstan population was ethnic Kazakhs, $41 \%$ ethnic Russians and $20 \%$ other ethnic groups (Ukrainians, Tatars, Chechens, etc.)

Here and further in this section, quotes from local news papers translated by author from Russian

8 In Kazakhstan, which has a population of 15 million inhabitants, small firms have 5 to 50 employees, medium firms 50 to 100 employees, and large companies are taken to be those with more than 100 employees. The holdings mentioned here had more than 1000 employees in 1997.
} 


\section{Empirical findings}

The findings reported in this paper are second-order analysis results (Gioia/Chittipeddi 1991) produced on the third stage of the research and based on a transversal analysis of all the data using the framework elaborated in the previous stages of analysis. This transversal analysis process was operated in the following manner:

1. The narratives collected from the group within a year and processed through category analysis produced first order analysis data. Internal documents and local press articles went independently through the same process.

2. The identification of homogeneous content and the patterns of change of that content resulted in the detection of five periods in managerial discourse evolution.

3. The comparison, period by period, of categorized content coming from group members' narratives with, on the one hand, categorized content of internal documents, and, on the other hand, that of media articles.

Figure: Second order data transversal analysis process

Thus, in this paper only the last stage, second order transversal analysis results will be reported. This analysis provided evidence that in their everyday lives, company managers developed and used a whole range of specific clichés, micromodels and convictions which were both acquired in their interaction and used in order to take action. The meanings attributed by the members of "New Generation" to various situations and activities proved to be a key to understanding their managerial practices.

\section{Five periods in the group history}

The analysis of the "New Generation" members' interviews revealed an apparent change in the meaning they gave to their businesses, to their roles and functions inside and outside their companies. The table 1 in Appendix A shows the changes in content of the respondents' representations of their roles, functions, identities, proclaimed objectives as well as the implicit objectives visible through the content analysis of their interviews. The interview content analysis revealed that the overall period of observation could be divided into five periods within which the respondents' ideas were homogeneous. Although the content of self-representation varies from one period to another, some elements remain stable and evolve in a cyclical way.

Appendix A: Evolution of the "New Generation" members' representations of the company manager's job. Summary of interviews content in five periods 


\begin{tabular}{|l|l|l|l|l|l|}
\hline Periods & 1991-1995 & 1996-1998 & 1999-2002 & $\mathbf{2 0 0 3 - 2 0 0 5}$ & $\mathbf{2 0 0 6 - 2 0 0 8}$ \\
\hline $\begin{array}{l}\text { Expressed } \\
\text { Objectives }\end{array}$ & $\begin{array}{l}\text { To create a } \\
\text { company, to } \\
\text { catch any } \\
\text { opportunity, to } \\
\text { find new } \\
\text { markets, new } \\
\text { products, new } \\
\text { methods, to } \\
\text { procure } \\
\text { finance, to } \\
\text { negotiate with } \\
\text { all kinds of } \\
\text { partners, } \\
\text { staffing. }\end{array}$ & $\begin{array}{l}\text { To optimize } \\
\text { structure, }\end{array}$ & $\begin{array}{l}\text { To create } \\
\text { favorable } \\
\text { conditions for } \\
\text { company } \\
\text { development }\end{array}$ & $\begin{array}{l}\text { To improve } \\
\text { the economic } \\
\text { conditions in } \\
\text { the country }\end{array}$ & $\begin{array}{l}\text { To assure the } \\
\text { sustainability } \\
\text { of the } \\
\text { company }\end{array}$ \\
\hline $\begin{array}{l}\text { Hidden } \\
\text { objectives }\end{array}$ & $\begin{array}{l}\text { Not } \\
\text { determined }\end{array}$ & $\begin{array}{l}\text { To legitimize } \\
\text { his new } \\
\text { position of } \\
\text { "company } \\
\text { owner" }\end{array}$ & $\begin{array}{l}\text { To project a } \\
\text { positive self- } \\
\text { image in } \\
\text { society, to find } \\
\text { his own identity } \\
\text { and style of } \\
\text { management }\end{array}$ & $\begin{array}{l}\text { To influence } \\
\text { different } \\
\text { decision } \\
\text { making } \\
\text { processes at } \\
\text { the State } \\
\text { level to his } \\
\text { advantage } \\
\text { and to gain } \\
\text { power }\end{array}$ & $\begin{array}{l}\text { To preserve } \\
\text { his private } \\
\text { property, to } \\
\text { reinforce his } \\
\text { social status }\end{array}$ \\
\hline
\end{tabular}




\begin{tabular}{|c|c|c|c|c|c|}
\hline Functions & $\begin{array}{l}\text { - day-to-day } \\
\text { management } \\
\text { - key accounts } \\
\text { management } \\
\text { - solve any } \\
\text { kind of } \\
\text { problems, } \\
\text { etc. }\end{array}$ & $\begin{array}{l}\text { - strategic } \\
\text { decision } \\
\text { making } \\
\text { - control } \\
\text { - day-to-day } \\
\text { manageme } \\
\text { nt }\end{array}$ & $\begin{array}{l}\text { - restructuring } \\
\text { - company } \\
\text { promotion } \\
\text { - company } \\
\text { development }\end{array}$ & $\begin{array}{l}\text { - (vague } \\
\text { definitions } \\
\text { by } \\
\text { respondent } \\
\text { s) } \\
\text { - lobbying }\end{array}$ & \begin{tabular}{|l} 
- assuring \\
group \\
cohesion \\
- searching \\
for \\
synergies
\end{tabular} \\
\hline Roles & $\begin{array}{l}\text { Entrepreneur } \\
\text { "Engine" of } \\
\text { the business }\end{array}$ & $\begin{array}{l}\text { Interface } \\
\text { between the } \\
\text { company } \\
\text { and the } \\
\text { outside } \\
\text { world }\end{array}$ & $\begin{array}{l}\text { Company } \\
\text { "protector", }\end{array}$ & $\begin{array}{l}\text { "promoter" } \\
\text { of ideas }\end{array}$ & $\begin{array}{l}\text { The } \\
\text { company's } \\
\text { "face" }\end{array}$ \\
\hline Competences & $\begin{array}{l}\text { On the } \\
\text { personal, } \\
\text { psychological } \\
\text { level } \\
\text { "smart" }\end{array}$ & $\begin{array}{l}\text { On the } \\
\text { intellectual } \\
\text { level }\end{array}$ & $\begin{array}{l}\text { On the } \\
\text { communication } \\
\text { level }\end{array}$ & $\begin{array}{l}\text { On the } \\
\text { political level }\end{array}$ & $\begin{array}{l}\text { On the social } \\
\text { level }\end{array}$ \\
\hline Self-image & $\begin{array}{l}\text { "new } \\
\text { generation" } \\
\text { manager }\end{array}$ & $\begin{array}{l}\text { "brain" of } \\
\text { his company }\end{array}$ & "strong leader" & $\begin{array}{l}\text { "responsible } \\
\text { citizen" }\end{array}$ & $\begin{array}{l}\text { "balanced } \\
\text { person" } \\
\text { "respectful } \\
\text { businessman" }\end{array}$ \\
\hline Place & $\begin{array}{l}\text { Everywhere in } \\
\text { the company }\end{array}$ & $\begin{array}{l}\text { At the center } \\
\text { of his } \\
\text { company }\end{array}$ & $\begin{array}{l}\text { On top of his } \\
\text { company }\end{array}$ & $\begin{array}{l}\text { Outside his } \\
\text { company, } \\
\text { and in } \\
\text { lobbies }\end{array}$ & $\begin{array}{l}\text { Within his } \\
\text { company and } \\
\text { within his } \\
\text { networks }\end{array}$ \\
\hline
\end{tabular}

\section{Period 1: 1991-1995}

During the first period, they assigned themselves the roles of "pioneers", "creators" and "challengers". They were not clear about their actions, but all of them wanted "to take quick actions", "to catch all opportunities", "to take advantage of the absence or irrelevance of certain laws and rules", "to create new possibilities for business development". Having neither knowledge nor experience in management and business, these entrepreneurs had to create their managerial practices and leadership style from scratch. In this first period, the entrepreneurs' approach to business was very simple and opportunistic:

"Just after the perestroika, the shortage of all kinds of goods was so severe, that everything brought in Kazakhstan was sold immediately. No marketing was needed, no advertising, nothing. We all ["New Generation" members] were involved in any business, providing it was profitable" ("NG" member interview quotes, June 1996).

Not surprisingly, company managers had an opportunistic approach and similar strategies not only within the group but allegedly in all post-soviet and Eastern 
European countries. This mechanism is described in a similar manner by many researchers from different countries in transition.

"By 1993, there were 25 employees in my company and we were involved in seven different businesses from importing computers from Moscow to Kazakhstan and chocolate bars from Germany, to real estate and travel agency businesses. N...n [name of another group member] sold [laughing] Toyota cars and chicken and eggs at that time!" ("NG” member interview quotes, June 1996).

\section{Period 2: 1996-1998}

During the second period, "New Generation" members decided to change their strategy with regard to their respective businesses. So, the most important decision of this period was to restructure the companies, which became highly diversified businesses, with no synergy between them and were more and more in competition with the businesses of other members of "New Generation". By that time the privatisation process had come to an end and the opportunistic approach to acquiring new firms was replaced by restructuring and optimizing strategies. During this period, the main data collected were internal documents such as "business plans", "restructuring memos" and acquisition documents. Most transactions (85\%) concluded between members of "New Generation" themselves, and few businesses were bought from or sold to outside owners. This period was also characterized by the group members' active learning. All of them reported having followed at least 5 weekly business seminars organized by newly emerged business schools and consulting companies. They had also sent their middle managers on different training programs.

"Not only me, but my colleagues too, we move forward by trial and errors. We've never done before, what we are doing now. And we never learnt how to do business. I have a biology diploma, ... [name of another respondent] is an engineer, and ...[name of another respondent] is a journalist. And we all have to manage huge, diversified businesses." ("NG" member interview quotes, October 1997).

Moreover, they had to legitimize their actions in society, where the majority of the population still believed in the old soviet values and was hostile to newly emerging capitalistic relationships. This is the reason for speaking not only about sensemaking but also about sensegiving.

During this period the membership in "New Generation" was considered a valuable resource and an undeniable force against political uncertainty, economic chaos, and institutional insufficiency. It was a possibility for them to co-create meaning and managerial practices. The data reported in this study describes the process of sensemaking in a very practical manner: each member of "New Generation" contributing to the construction of the common meaning of a changing environment and of the relevant response to these changes. Practically, when one member of the group discovered a useful tool, innovative 
method or found interesting information, he brought it to the attention of the group for discussion, evaluation or testing. Thus, some ideas, tools or techniques were rejected; others evolved and strengthened through discussion and were kept for practice by the members of the group.

\section{Period 3: 1999-2002}

In the next period, the vulnerability of new businesses, their dependence and unstable character, as well as the absence of guarantees securing private property pushed new business elites to penetrate legislative and government structures. Two of the respondents became members of Parliament, 2 took Ministerial posts, 1 became Vice-Minister, 3 of them were appointed as Executive Directors of huge public companies, whereas the others remained at the head of their own companies.

"Two reasons pushed me to enter the government. First of all, I had acquired so much experience in managing my companies that I felt I was able to manage a Ministry, which was poorly managed by old Soviet apparatchiks. It couldn't be worse. And secondly, it was a personal challenge for me. You remember, I told you once, my slogan is 'the sky is the limit' and decided to prove to myself that I was capable of becoming a minister at 36." ("NG" member interview quotes, September 2001).

Their employment in these posts did not last long and was not always successful, but as our respondents recognized themselves, this management experience was worthwhile in terms of understanding power distribution at the State level.

"For me the reason [for becoming a Member of Parliament] was very simple and pragmatic: you cannot be totally secure in this country unless you are close to the power structures." ("NG” member interview quotes, September 2001).

\section{Period 4: 2003-2005}

This period was similar to the previous one, with the difference that some of "New Generation" members confronted the presidential power by creating a new opposition party. This period's data suggested that the change in the meaning of their managerial work was not necessarily a result of the new social status or new functions of individual members of "New Generation". Curiously, when only a few of them got involved in a new activity and therefore changed the content of their discourse on their practices, other members, who did not have the same experience, delivered a similar discourse. The following example clearly explains this mechanism. When, in 2003, two members of the "New Generation" organized a political party and three more expressed publicly their support for this initiative, the remaining five members were skeptical about the usefulness of this action. Nonetheless, in the interviews at the end of 2004, they identified themselves as a "new political force in Kazakhstan", and their selfperception changed in the same way as that of their co-members involved in 
politics. The interviews of this period contained a large number of sentences referring to political topics (bearing in mind that questions asked remained the same and focused on managerial practices and respondents' strategic actions): "lack of transparency", "dictatorship", "tribalism and nepotism", "incompetence of government and administration", "corruption", etc. Surprisingly, in 2004, after their political party was defeated, such expressions completely disappeared from the last series of interviews. New vocabulary invaded the narratives of all the group members: "effectiveness and efficiency", "managerial excellence", "strategic and international development of the company", "competitive advantage"; or otherwise "humanism", "charity actions", "ethical business", "Kazakh culture promotion" and so on.

\section{Period 5: 2006-2008}

The last period of observation showed the group members concentrated on the development of their private businesses and participation in different business and professional associations, like the Congress of Entrepreneurs of Kazakhstan, the Forum of Employers of Kazakhstan, etc.

\footnotetext{
"We should not fight on their ground [politics], since we are going against their interests [power incumbents in Kazakhstan] and we will always loose. We should develop business practices, professional management, the competitiveness of Kazakh companies and their integration in the world economy. And through these practices we can win, I mean, we can steadily establish a normalized market economy from the bottom even though the top remains corrupt and unprofessional." ("NG" member interview quotes, July 2004).
}

By the end of the observation period, the respondents' narratives were more and more influenced by the ideological framework, either coming from the dominant Kazakh ideology or from Western management theory and practices. During the last series of interviews, respondents described their activities in terms of "gaining competitive advantage", "creating shareholder value", etc., whereas at the beginning of the study in 1997, they spoke about "surviving", "finding their way in the chaotic landscape", "adopting an appropriate management style", "securing their businesses", and so on.

\section{Discussion}

The empirical findings, briefly introduced in the previous section, will be now discussed more in detail. In the literature on countries in transition (Matonyte 1998; Nutti, 1996; Mink/ Szurek 1992) researchers often argue that during the transition period the new managerial discourse completely replaces the old one based on Soviet management and plan economy. This section will explain by which channels and in which forms, management practices appear and evolve in transition economies. 
This study endeavored to understand how a group of managers/owners having emerged in the chaotic environment of a transition period could construct coherent managerial narratives reflecting "normalized" managerial practices. In the post-Soviet countries of the early nineties Western managerial knowledge was not yet available; local business schools, training centers and consulting companies had not yet emerged and ignorance of the English language prevented young businessmen from studying abroad. How did these new managers of private companies in general and "New Generation" members in particular develop their practices and make sense of their job and of the hectic environment of a transition period?

Based on the theories of sensemaking and social representation, this paper conceptualizes the mechanism of creating meaning in the form of small scale loops between context observation, verbal interactions and actions, occurring within a framework provided by the social construct: culture, ideology, and social practices.

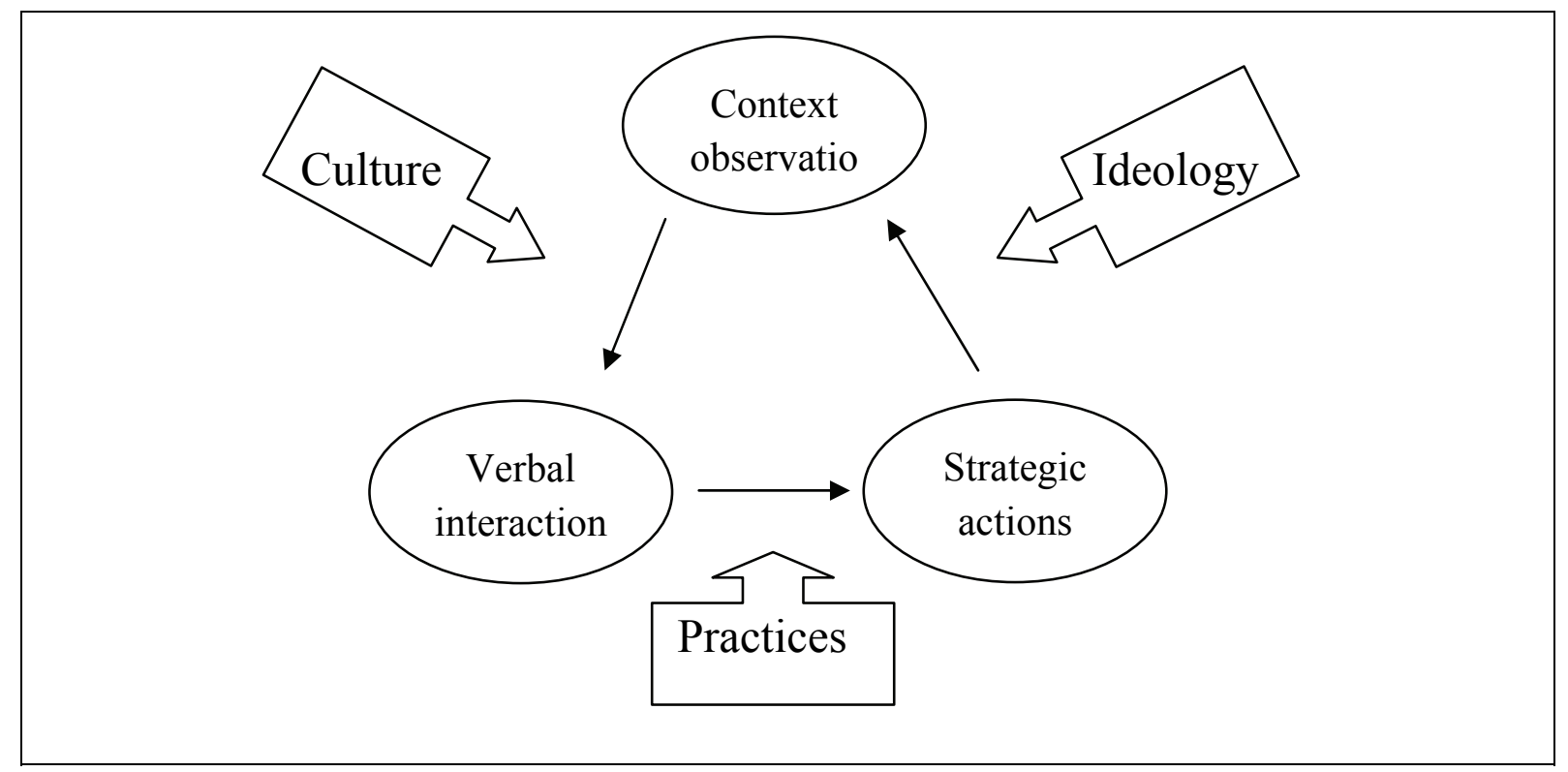

In post-Soviet countries, new managerial practices emerged through an active process of sense-seeking and sensemaking within social interactions. In different periods of this study the influence of national culture, dominant ideology and social practices varied. At the beginning, the process of meaning building was mostly driven by social practices, by the need to understand the transitional context and to take appropriate action. In the later stages of this process the weight of ideology grew increasingly. First of all, the Kazakh dominant ideology and official discourse supplied key directions, ideas and vocabulary; later on, Western managerial discourse invaded the ground and almost replaced sensemaking. 


\section{Mechanism of creating meaning in managerial work}

The empirical results show that the group studied in this research constructed common and shared meaning around their managerial activities, the context and themselves. These representations find their expression in the different forms of communication as well as in the strategic actions of the group members. The role of interaction within the group is not limited to "making sense" of past actions and events, but it also drives future actions, which, in turn, have an impact on members' representations.

When this group emerged, in this most uncertain and turbulent period, their practical experience and group interaction had great impact on their practices. Indeed, they did not have any official references enabling them to understand the context. The old soviet ideology had already been rejected, whereas the new one had not yet been established. Western management theory, explaining the essence of managerial practices, was not yet accessible. The previous common knowledge contained in the collective memory of the Kazakh society could not give a relevant explanation of "What was happening at that period" and "What to do" in this new situation.

For each new 'socially significant' object, the group consensus produced a 'referential representation' integrated in the common cognitive system. The representation of an object can be acquired or espoused by a group, when it already exists, or needs to be constructed if the object is completely new. This 'referential representation' provides an internal source of coherence for the group members and, at the same time, constrains their social behavior. The 'referential representation' provides a kind of grid for making sense of ambiguous situations reflected by the individual's mental images and consequently makes adequate action possible.

The study shows that meaning was built by the group in a contingent and singular context, which included the country's authorities, cultural and ideological artifacts as well as the actions and meanings of the other social actors. Cultural elements are recognized as being of high importance in strategic change processes (Johnson 1990; 1992). This study suggests that the central elements of meaning remained stable during the whole period of the study.

Anchorage in the dominant ideology endows the representations with legitimacy and social acceptability at a given moment. The official ideological discourse triggers the development of peripheral elements of representation which act as a link between deep seated central elements and the ongoing discourse. These elements provide flexibility to individual representations and adapt them to the prevailing beliefs.

The role of social practices is to keep individuals' representations in line with the reality of the context and therefore to ensure the relevance of their actions. At the same time, practitioners produce new social objects, meanings and 
common knowledge (Samra-Fredericks 2003). They shape the world at the same time as it shapes them, speaking in Gidden's (1984) and Bourdieu's (1994) terms.

The content analysis of top managers' narratives revealed a significant instability in the meaning of the managerial job that was deeply embedded in the social context. The more hectic and uncertain the environment was, the more unstable managers' representations about their work. This observation probably makes sense only in a transitional background, where rapid changes in the environment require quick cognitive adaptation and therefore constantly evolving representations.

\section{Self-representation and group identity in the meaning creation process}

This study suggests that company CEO's identity cannot be categorized as a construct with rigid boundaries, especially during periods of rapid change and social instability. The observation of "New Generation" members revealed the importance of their self image and belongingness to the group in constructing the meaning of their managerial practices. In describing their experiences and future plans, respondents repeatedly talked about how their self-conceptions were related to their steadily changing practices and roles. Clearly, such selfconceptions played a major role in the process of sensemaking of their environment and their own actions. "Managers tend to view the world through categories relevant to their present situation. (Isabella 1988: 356)"

The need for internal coherence encourages individuals to adopt the strategies compatible with overall group beliefs. This finding, coupled with the other conclusions, suggests that the meaning of the managerial practices is closely related to the self- representation of the group members. In the particular case of the "New Generation", business strategies are tightly linked with personal strategies and vice versa; self-representation is closely related to representations of managerial practices, functions and roles: they follow each other, influence each other and reshape each other in the small scale loops process.

The findings of the empirical study show that the self-representation of the "New Generation" members evolves in the same direction and with the same pattern as their representation of their managerial practices, roles and functions. It is important to mention that separate analysis of self-identity, expressed in the interviews of the group members and analysis of their image in the society and identified through articles and documentary screening, show only some insignificant differences between them. This conformity between self-identity and social image can be explained by the fact that the entire group communicated effectively about themselves and their company in the media, in order to gain a positive image and strengthening their social position. 
To conclude this section, sensemaking processes organize group relationships around common meanings, reducing the complexity and uncertainty of the business context, and providing assertions, beliefs and practical knowledge for use in the managers' respective activities. Uncertainty reduction is a core human motivation. Certainty renders existence meaningful and confers confidence in how to behave and what to expect from the physical and social environment (Hogg/Terry 2000; 1992). At the same time, individuals' representations and practices are dependent on their position in the society, which seems to organize their various social roles and to provide, if not impose, the framework for sensemaking (Fiske/Taylor 1991).

\section{Conclusion}

The purpose in this paper was to explore the process of interaction between managerial, practices, representations, identity, and discourse. In particular, the author wished to explore this relationship in the context of a transition economy where all these elements were unstable due to fast changing conditions of the transformation process.

The final narratives of "New Generation" members give accounts of "normalized" managerial practices. In the conversations they all use the generally accepted vocabulary of Western management discourse. But does it mean that they really constructed Western type managerial practices or they have just learnt to use the discourse? Strategic actions analysis revealed that managerial practices of "New Generation" managers are still very different from those of leaders in western countries. But the last interviews and written documents showed their ability to use management concepts, often in appropriate way. Transversal analysis showed also that "New Generation" strategic actions were more efficient at the beginning of their career. Individually and collectively they made more bad decisions during the later periods of the study than at its beginning. This paper argues that wrong actions were made on the basis of erroneous meaning attributed by the group to the situation. This meaning arose from initial sensemaking process which meant that an official discourse becomes institutionalized. The group almost stopped reflecting on the discourse and ideological anchorage became dominant.

The theoretical contribution stemming from this conclusion is that managers involved in an active process of sensemaking, in which anchorage in the cultural, ideological and practical constructs is well balanced, are more likely to build the most fitting meanings and consequently to take appropriate actions, i.e. actions resulting in desired outcomes in a specific contextual setting. Those who only rely on management discourse, who do not ask themselves the right questions, are more likely to come up with inappropriate answers, leading to managerial practices that do not meet their expectations in terms of results. 
Thus a key implication to be drawn from these results is that studies on managers should not be restricted to examining their occupational roles and functions only at the firms where they work. Another contribution of this research consists in the study of company top managers as socially competent players (Rouleau 2005), whose sensemaking activities are not bounded by the frontiers of the organization and their managerial roles and functions. Strategists are above all active social players with their own personal ambitions. They have their own subjective views about the ethics, the feasibility and scope of their actions. Indeed, the strategies and representations, formed in the interaction between a manager and his/her environment, only exist because of the consistency of the internal processes orienting and constraining his/her social conduct and actions.

Secondly, the managerial practices, the discourse and the representations of a social group are in a relation of co-production. The tight interactions between the members of the group, their identification to "New Generation", mutual trust as well as the convergence of their interests participate in the construction of group cohesion, well orchestrated strategic actions, shared representations and common practices. Meaning is built by the group in a contingent and singular context, and includes the country's authorities, cultural and ideological factors as well as the actions and meanings of the other social actors.

Thus, this study contributes to understanding the role of the group in interpreting ambiguous information and ascribing it a relevant meaning, especially within a transitional context. It offers an innovative approach for the study of the development of managerial practices as a process of talk-based interaction relating managerial representations, rooted in social context and managerial discourse as a function of situation based expressed identity.

The majority of the research on managerial cognition is carried out on a snapshot basis. This kind of research does not take into account the long-range process of the evolution of managers' representations and cannot observe its implications for their strategic actions. One of the contributions of this study consists in the introduction of the temporal aspect and the follow-up of the evolution of the group of managers over a long period of time. Exploring the stability or instability of managers' representations in Western society may be a fruitful avenue for future research.

Although this study provides significant empirical and theoretical insights, there are several limitations worth addressing here. Despite an attempt to show the subtleness of the change process in managerial practices in a particular context, not all the elements have received sufficient attention to create a comprehensive description of this process. This process is rather more complex, fragile and dynamic than this paper reveals. In everyday managerial practices, company managers deal with complexities and ambiguities which demand a great deal of 
improvisation, of micro-decisions and choices. Despite an attempt to show the subtleness of the process of emergency and change in managerial practices in a particular context, not all the elements of this process have received sufficient attention in the process of creating a comprehensive and dynamic narrative.

The results of this study have several implications for organizational theory and practices. Our understanding of the process of managerial practice development is incomplete until we better understand how tacit knowledge or practical wisdom gained from social interactions between individuals and groups translates into managerial discourse. The intersection between sensemaking and social representation theories has great but yet largely unexplored potential for our understanding of manager thinking and acting. This paper has tried to energize this potential by describing various speculations, based on empirical research, and some propositions that can act as a framework for future research.

\section{References}

Ashfort, B.E./Mael, F. (1989): Social identity theory and the organization, in: Academy of Management Review, 14, 20-39

Baumeister,R.F./Leary, M.R. (1995): The need to belong: Desire for Interpersonal Attachments as a Fundamental Human Motivation, Psychological Bulletin, 117, 3, 497-529.

Berger, P./Luckmann T. (1967): The Social Construction of Reality, New York: Anchor Books.

Beyer, J.M./Hannah D.R. (2002): Building on the Past: Enhancing Established Personal Identities in a New Work Setting, Organization Science, 13, 6, 636-652.

Bourdieu, P. (1994): Structures, habitus, power: basis for a theory of symbolic power, in: Dirks, N.B./Eley G./Ortner S.B. (eds.): Culture/power/history: a reader in contemporary social theory, Princeton University Press, Princeton, NJ, 155-199.

Cossette, P./Audet M. (1992): Mapping of an idiosyncratic schema, in: Journal of Management Studies, 29, 3, 326-347.

Drew, P./Heritage J. (eds) (1994): Talk at Work: Interaction in Institutional Settings, Cambridge: Cambridge University Press.

Dutton, J. E./Jackson S. E. (1987): Categorizing Strategic Issues: Links to Organizational Action, Academy of Management Review, 12, 1, 76-90.

Eden, C. (1992): On the nature of cognitive maps, in: Journal of Management Studies, 29, 3, 262-265.

Fiol, C. F./Huff A. S. (1992): Maps for managers: Where we are? Where do we go from here?, in: Journal of Management Studies, 21, 3, 267-285.

Feldman, S.D. (1979): Nested identities, in: Denzin, N.K. (ed.): Studies in Symbolic Interaction, Vol. 2, Greenwich: JAI Press, 399-418.

Foreman, P./Whetten D.A. (2002): Members' Identification with Multiple-Identity Organizations, in: Organization Science, 13, 6, 618-635. 
Fotaki, M. (2009): Maintaining the illusion of a free health care in post-socialism. A Lacanian analysis of transition from planned to market economy, in: Journal of Organizational Change Management, 22, 2, 141-158.

Fiske, S.T./Taylor S.E. (1991): Social Cognition, New York: McGraw-Hill.

Fiss, P.C./Zajac E.J. (2006): The symbolic management of strategic change: Sensegiving via framing and decoupling, in: Academy of Management Journal, 49, 6, 1173-1193.

Giddens, A. (1984): The Constitution of Society: Outline of the Theory of Structuration, Berkeley: University of California Press.

Gioia, D. A./Mehra A. (1996): Sensemaking in organizations, in: Academy of Management Review, 21, 1226-1231.

Gioia, D. A./Chittipeddi K. (1991): Sensemaking and sensegiving in strategic change initiation, in: Strategic Management Journal, 12, 433-448.

Goffman, E. (1959): The Presentation of Self in Everyday Life, New York: Anchor Books.

Grize J-B./Vergès P./Silem A. (1987): Salariés face aux nouvelles technologies, Paris: CNRS / Centre régional de publication de Lyon.

Hogg, M.A./Terry D.J. (2000): Social Identity and Self-Categorization Processes in Organizational Contexts, in: Academy of Management Review, 25, 1, 121-140.

Huff, A.S. (1990): Mapping Strategic Thoughts, New York: Wiley.

Jodelet, D. (ed.) (1989): Les représentations sociales, Paris: PUF.

Jodelet, D. (1984): Représentations sociales : phénomène, concepts et théorie, in: Moscovici, S. et al.: Psychologie sociale, Paris: PUF.

Johnson, G. (1990): Managing strategic change; the role of symbolic action, in: British Journal of Management, 1, 182-200.

Johnson, G. (1992): Managing strategic change - strategy, culture and action, in: Long Range Planning, 25, 1, 28-36.

Isabella, L.A. (1988): The effect of career stage on the meaning of key organizational events, in: Journal of Organizational Behavior, 9, 345-358

Isenberg, D. J. (1986): Thinking and managing: a verbal protocol analysis of managerial problem solving, in: Academy of Management Journal, 29, 4, 775-778.

Laroche, H. (1995): From decision to action in organization: Decision-making as a social representation, in: Organization. Science, 6, 1, 62-75.

Lavigne, M. (1995): The Economies in Transition: From Social Economy to Market Economy, London: MacMillan.

Matonyte, I. (1998): Grille d'analyse de l'élite économique post-soviétique, in: Revue d'études comparatives Est - Ouest, 28, 1, 98-117.

Mead, G.H. (1934), Mind, Self and Society, Chicago: University of Chicago Press.

Mink, G./Szurek J.-Ch. (1992): Cet étrange post-communisme. Rupture et transition en Europe centrale et orientale, Paris: La Découverte / Presses du CNRS.

Moscovici, S. (1961): La psychanalyse, son image et son public, Paris: PUF.

Moscovici, S. (ed.) (1984): Psychologie sociale, Paris: PUF. 
Murray, S.L./Holmes, J.G./Collins, N.L. (2006): Optimizing Assurance: The Risk Regulation System in Relationships, in: Psychological Bulletin, 132, 5, 641-666.

Nutti, D.M. (1996): Post Communist Mutation, in: Journal of Transforming Economies and Societies, 3, 1, 53-67.

Pettigrew A. (ed.) (1987): The Management of Strategic Change, London: Basil Blackwell.

Pettigrew A. (1990): Studying strategic choice and change, in: Organization Studies, 11, 6-11.

Pettigrew A. (1992): On Studying Managerial Elites, in: Strategic Management Journal, 13, 163-182.

Pratt, M.G./Foreman, P.O. (2000): Classifying Managerial Responses to Multiple Organizational Identity, in: Academy of Management Review, 25, 1, 18-42.

Rouleau, L. (2005), Micro-practices of Strategic Sensemaking and Sensegiving: How Middle Managers Interpret and Sell Change Every Day, in: Journal of Management Studies, $42,7,1414-1441$.

Samra-Fredericks, D. (2003): Strategizing as Lived Experience and Strategists' Everyday Efforts to Shape Strategic Direction, in: Journal of Management Studies, 40, 1, 141174.

Thomas, J. B./Clark, S. M./Gioia, D. A. (1993): Strategic sensemaking and organizational performance: linkages among scanning, interpretation, action, and outcomes, in: Academy of Management Journal, 36, 2, 239-270.

Turner, J.C. (1985): Social categorization and the self-concept: A social cognitive theory of group behaviour, in: Lawler, E.J. (ed.): Advances in group processes: Theory and research, Vol. 2., Greenwich: JAI Press, 77-122.

Weick, K. E. (2005): Organizing and the Process of Sensemaking, in: Organization Science, $16,4,409-421$. 